\title{
Association of (pro)renin receptor gene polymorphisms with lacunar infarction and left ventricular hypertrophy in Japanese women: the Ohasama study
}

\author{
Takuo Hirose ${ }^{1}$, Masahiro Hashimoto ${ }^{1}$, Kazuhito Totsune ${ }^{1,2}$, Hirohito Metoki ${ }^{3}$, Azusa Hara ${ }^{4}$, Michihiro Satoh ${ }^{1}$, \\ Masahiro Kikuya $^{1}$, Takayoshi Ohkubo ${ }^{1,5}$, Kei Asayama ${ }^{1}$, Takeo Kondo ${ }^{6}$, Kei Kamide ${ }^{7}$, Tomohiro Katsuya ${ }^{8}$, \\ Toshio Ogihara ${ }^{9}$, Shin-Ichi Izumi ${ }^{6}$, Hiromi Rakugi ${ }^{7}$, Kazuhiro Takahashi ${ }^{10}$ and Yutaka Imai ${ }^{1}$
}

Recent studies have revealed that (pro)renin receptor ((P)RR), a newly identified member of the renin-angiotensin system, is associated with organ damage that occurs with cardiovascular disease. We investigated the association of genetic polymorphisms in the (P)RR gene with lacunar infarction, white matter hyperintensity and left ventricular hypertrophy (LVH) in a Japanese general population recruited from the Ohasama study, a Japanese cohort study. A total of 779 subjects ( $m e n=250$ and women $=529$ ) were recruited. For the association study, we selected three polymorphisms: $-782 \mathrm{~A}>\mathrm{G}$ (rs2968915), intervening sequence (IVS)5+169C $>T$ (rs5918007) and +1513A $>$ G (rs6609080). In women, the prevalence of lacunar infarction and LVH was significantly higher in subjects with the +1513GG genotype than in those with the AA or AG genotypes (lacunar infarction: $P=0.01$, LVH: $P=0.003$ ). Plasma renin activity (PRA) levels in women with the GG genotype were significantly lower than in women with the $A A$ or $A G$ genotypes $(P=0.01)$. Multiple logistic regression analysis adjusted for confounding factors demonstrated that $+1513 A>G$ polymorphism was significantly and independently associated with the risk of lacunar infarction (trend $P=0.03$ ) and LVH (trend $P=0.003$ ). In men, there were no significant differences in lacunar infarction, LVH or PRA levels among the three genotypes. The polymorphism of the (P)RR gene $+1513 A>G$ is associated with lacunar infarction and LVH in Japanese women. These results suggest that (P)RR has a role in organ damage in humans. Hypertension Research (2011) 34, 530-535; doi:10.1038/hr.2010.274; published online 13 January 2011

Keywords: organ damage; polymorphism; (pro)renin receptor; renin-angiotensin system

\section{INTRODUCTION}

(Pro)renin receptor ((P)RR), a specific receptor for renin and prorenin, was identified as a member of the renin-angiotensin system (RAS) by Nguyen et al. ${ }^{1}$ (P)RR is a 350 amino-acid protein with a single transmembrane domain and is widely expressed in various tissues including the heart, kidney and brain. ${ }^{1-3}$ When bound to prorenin, $(\mathrm{P}) \mathrm{RR}$ activates the angiotensin I-generating activity of prorenin in the absence of cleavage of the prosegment, and directly stimulates $\mathrm{p} 42 / \mathrm{p} 44$ mitogen-activated protein kinase activation and transforming growth factor- $\beta 1$ release independently from the RAS. ${ }^{1,4}$ Several animal studies have shown that (P)RR contributes to the development of end-organ damage. ${ }^{5-12}$ Ichihara et al. ${ }^{6,7}$ reported that development of renal damage in stroke-prone spontaneously hypertensive rats and diabetic rats was ameliorated by blocking (P)RR with handle region peptide, a peptide corresponding to the handle region of the prorenin prosegment. Kinouchi et al. ${ }^{11}$ reported that cardiomyocyte-specific ablation of (P)RR inevitably resulted in heart failure and the mice died within 3 weeks of birth. We recently reported increased gene expression of $(\mathrm{P}) \mathrm{RR}$ in the hearts and kidneys of rats with congestive heart failure, ${ }^{13}$ and increased expression of (P)RR in the remnant kidneys of 5/6 nephrectomized rats, ${ }^{14}$ suggesting that $(\mathrm{P}) \mathrm{RR}$ has a role in blood pressure regulation and its accompanying end-organ damage.

The (P)RR gene is on chromosome Xp11.4 in humans. ${ }^{1}$ A genomewide association study reported that chromosome Xp11 was linked with diastolic blood pressure. ${ }^{15}$ The mutation of the (P)RR gene

\footnotetext{
${ }^{1}$ Department of Planning for Drug Development and Clinical Evaluation, Tohoku University Graduate School of Pharmaceutical Sciences and Medicine, Sendai, Japan; 2Department of Social Welfare, Faculty of Synthetic Welfare, Tohoku Fukushi University, Sendai, Japan; ${ }^{3}$ Department of Obstetrics and Gynecology, Tohoku University Graduate School of Medicine, Sendai, Japan; ${ }^{4}$ Epidemiology and Prevention Division, Research Center for Cancer Prevention and Screening, National Cancer Center, Tokyo, Japan; ${ }^{5}$ Department of Health Science, Shiga University of Medical Science, Otsu, Japan; ${ }^{6}$ Department of Physical Medicine and Rehabilitation, Tohoku University Graduate School of Medicine, Sendai, Japan; ${ }^{7}$ Department of Geriatric Medicine and Nephrology, Osaka University Graduate School of Medicine, Suita, Japan; ${ }^{8}$ Department of Clinical Gene Therapy, Osaka University Graduate School of Medicine, Suita, Japan; ${ }^{9}$ Osaka General Medical Center, Osaka Prefectural Hospital Organization, Osaka, Japan and ${ }^{10}$ Department of Endocrinology and Applied Medical Science, Tohoku University Graduate School of Medicine, Sendai, Japan

Correspondence: Dr T Hirose, Department of Planning for Drug Development and Clinical Evaluation, Tohoku University Graduate School of Pharmaceutical Sciences and Medicine, 6-3 Aramaki-aza-Aoba, Aoba-ku, Sendai 980-8578, Japan.

E-mail: hirose-t@m.tains.tohoku.ac.jp
}

Received 28 September 2010; revised 8 November 2010; accepted 9 November 2010; published online 13 January 2011 
results in X-linked mental retardation and epilepsy. ${ }^{16}$ Moreover, the polymorphism of the (P)RR gene intervening sequence (IVS)5+ $169 \mathrm{C}>\mathrm{T}$ is associated with blood pressure levels in Japanese men ${ }^{17}$ and in Caucasian men. ${ }^{18}$ These studies have suggested that the (P)RR gene is a candidate gene for hypertension and cardiovascular and cerebrovascular disease. In humans, however, little is known of the association of $(\mathrm{P}) \mathrm{RR}$ with cardiac and cerebral disorders. In this study, we investigated the association of genetic polymorphisms in the $(\mathrm{P}) \mathrm{RR}$ gene with lacunar infarction, white matter hyperintensity (WMH) and left ventricular hypertrophy ( $\mathrm{LVH})$ in a Japanese general population recruited from the Ohasama study.

\section{METHODS}

\section{Design and study population}

This study was a part of the Ohasama study and based on data obtained from subjects who participated in our blood pressure monitoring and genetic analysis project in a rural community of Ohasama, Iwate Prefecture, Japan. The characteristics of this area and details of the study design have been described previously. ${ }^{19,20}$ The study protocol, including the genetic analysis, was approved by the Institutional Review Board of Tohoku University School of Medicine and by the Department of Health of the Ohasama Town Government.

In 1998, the total population of Ohasama was 7202. Of these inhabitants, 3077 were older than 55 years. People who were hospital in-patients, mentally ill or bedridden were excluded $(n=185)$. People who worked outside the town were also excluded $(n=492)$, because our project included ambulatory blood pressure (ABP) measurements, which required public health nurses to visit the individuals and attach a device for $\mathrm{ABP}$ monitoring during the day on working days. Of the remaining 2400 eligible individuals, 779 subjects (mean age: 65.7 years, $32.1 \%$ men) who gave written informed consent, and had full clinical characteristics, biochemical parameters, $\mathrm{ABP}$ values and information on genotypes available were included in the analysis. Of those, 738 subjects who completed magnetic resonance imaging scans and had no history of previous stroke or transient ischemic attack were included in the analysis of silent cerebrovascular lesions, and 662 subjects who completed the measurements of standard 12-lead electrocardiograms were included in the analysis of LVH.

At public health centers, trained nurses of Ohasama town measured anthropometric characteristics. Study nurses administered a standardized questionnaire, inquiring into medical history, intake of medications, and smoking and drinking habits of each patient. Previous cardiovascular disease included stroke, transient ischemic attack, coronary heart disease and atrial fibrillation. Venous blood samples were analyzed using standard automated enzymatic methods for total cholesterol and blood glucose. Biochemical parameters, such as lipid profiles, electrolytes and serum creatinine levels were measured with an autoanalyzer. Plasma renin activity (PRA) was determined by angiotensin I generation (angiotensin I (ng)/plasma $(\mathrm{ml}) /$ incubation time $(\mathrm{h})$ ) by SRL (Tokyo, Japan). Diabetes mellitus was defined as a fasting or random blood glucose level of $\geqslant 7.0$ or $\geqslant 11.1 \mathrm{mmoll}^{-1}$, respectively, or as the use of antidiabetic drugs. ${ }^{21}$ Hypercholesterolemia was a serum level of total cholesterol of $\geqslant 5.68 \mathrm{mmoll}^{-1}\left(220 \mathrm{mg} \mathrm{dl}^{-1}\right)$ or use of lipid-lowering drugs.

\section{Blood pressure measurements}

Details of ABP monitoring have been described previously. ${ }^{19,22}$ In brief, ABP was monitored every $30 \mathrm{~min}$ using a fully automatic device (ABPM 630; Nippon Colin, Komaki, Japan). Mean 24-h, daytime and nighttime values for ABP were calculated for each participant. 'Daytime' and 'nighttime' were determined according to each participant's diary. We thus analyzed ABP data obtained during $>6 \mathrm{~h}$ of daytime and $>3 \mathrm{~h}$ of nighttime. The mean number of measurements was $43.5 \pm 4.9$ per subject.

Casual blood pressure, measured by public health nurses or technicians using an automatic device (HEM 907; Omron Healthcare, Kyoto, Japan), was measured twice consecutively with subjects in the sitting position, with a minimum 2-min rest between measurements. The mean of the two measurements was used for analysis.

Devices used to measure $\mathrm{ABP}$ or casual blood pressure met the criteria of the Association for the Advancement of Medical Instrumentation. 22,23
Hypertension was defined as 24-h systolic blood pressure $\geqslant 130 \mathrm{~mm} \mathrm{Hg}$ and/ or 24-h diastolic blood pressure $\geqslant 80 \mathrm{~mm} \mathrm{Hg}$ and/or use of antihypertensive medications. $^{24}$

\section{Lacunar infarction and white matter hyperintensity}

The evaluation procedure for lacunar infarction and WMH using magnetic resonance imaging has been reported elsewhere. ${ }^{25}$ In brief, we obtained MR images using a superconducting magnet with a main $0.5-\mathrm{T}$ coil. The brain was imaged in the axial plane in 10-mm-thick slices, and T1- and T2-weighted images were collected. A lacunar infarction was defined as an area of low signal intensity measuring $\leqslant 15 \mathrm{~mm}$ and $\geqslant 3 \mathrm{~mm}$ in diameter on T1-weighted images and a corresponding obvious high signal intensity area on $\mathrm{T} 2$-weighted images. A silent lacunar infarction was defined as the presence of hyperintensity on a T2-weighted image and a corresponding obvious low-intensity area on a T1-weighted image. Hyperintense punctuate lesions evident only on the T2-weighted images were not counted as lacunar infarction. We defined WMH as hyperintensities on only T2-weighted images. Small caps $(<5 \times 10 \mathrm{~mm})$ on the horns of the lateral ventricles and pencil-thin lining around the ventricles were considered normal. Larger caps $(\geqslant 5 \times 10 \mathrm{~mm})$ were considered WMH.

\section{Left ventricular hypertrophy}

LVH was diagnosed with standard 12-lead electrocardiograms as described previously. ${ }^{26}$ According to the criteria of the Losartan Intervention For Endpoint Reduction in Hypertension study, ${ }^{27}$ we defined LVH as follows: Cornell voltage-duration product $((\mathrm{RaVL}+\mathrm{SV} 3) \times \mathrm{QRS}$ duration, in men; $(\mathrm{RaVL}+\mathrm{SV} 3+0.6) \times \mathrm{QRS}$ duration, in women) $>244 \mathrm{mV} \times \mathrm{ms}$, and/or Sokolow-Lyon voltage $(\mathrm{SV} 1+\mathrm{RV} 5 / 6)>3.5 \mathrm{mV}$. The $\mathrm{R}$ waves in leads aVL, $\mathrm{V} 5$ and V6 and $\mathrm{S}$ waves in leads $\mathrm{V} 1$ and $\mathrm{V} 3$ were measured to the nearest $0.05 \mathrm{mV}$.

\section{Genetic analysis}

On the basis of linkage disequilibrium between (P)RR single-nucleotide polymorphisms (SNPs), we genotyped three SNPs: $-782 \mathrm{~A}>\mathrm{G}$ (rs2968915) in the promoter region, IVS5+169C $>\mathrm{T}$ (rs5918007) in intron5, and $+1513 \mathrm{~A}>\mathrm{G} \quad(\mathrm{rs} 6609080)$ in the $3^{\prime}$-untranslated region, as previously described. ${ }^{17}$

\section{Statistical analysis}

Statistical analysis was performed with the JMP 5.0.1 statistical software package (SAS Institute, Cary, NC, USA). As the (P)RR gene is on the $\mathrm{X}$ chromosome, men and women were analyzed separately. Student's $t$-test, $\chi^{2}$-test, analysis of variance and analysis of covariance were used where appropriate. A multiple logistic regression model was used to determine whether $(\mathrm{P}) \mathrm{RR}$ gene polymorphisms were associated with lacunar infarction, WMH and LVH after adjustment for cardiovascular risks. Continuous values were expressed as means \pm s.d. PRA levels were expressed as medians with interquartile ranges, and transformed into natural logarithm before the association analysis. Differences of $P<0.05$ were considered statistically significant.

\section{RESULTS}

Clinical characteristics, prevalence of lacunar infarction, prevalence of $\mathrm{WMH}$, prevalence of $\mathrm{LVH}$ and blood pressure values of the study population by gender are shown in Table 1 . The clinical characteristics, including smoking habits, drinking habits, prevalence of hypertension, prevalence of hypercholesterolemia, blood pressure values, serum creatinine and PRA were significantly different between men and women. The genotype frequencies of each SNP in the total population are shown in Table 2. The genotype frequencies of each SNP were consistent with the Hardy-Weinberg equilibrium in women (as the (P)RR gene is located on the $\mathrm{X}$ chromosome, genotype data were omitted in men), and there were no significant differences in allele frequencies between men and women.

In women, there was significant association between the genotype of $+1513 \mathrm{~A}>\mathrm{G}$ and the prevalence of lacunar infarction and $\mathrm{LVH}$ 
Table 1 Population characteristics

\begin{tabular}{|c|c|c|c|c|}
\hline & Total & Men & Women & P-value \\
\hline Number of subjects & 779 & 250 & 529 & \\
\hline Age, years & $65.7 \pm 5.6$ & $66.1 \pm 5.4$ & $65.5 \pm 5.6$ & 0.2 \\
\hline Current smoker, \% & 14.1 & 40.8 & 1.5 & $<0.0001$ \\
\hline Current drinker, \% & 27.2 & 65.6 & 9.1 & $<0.0001$ \\
\hline Diabetes mellitus, \% & 13.9 & 17.2 & 12.3 & 0.07 \\
\hline Hypercholesterolemia, \% & 18.2 & 8.0 & 23.1 & $<0.0001$ \\
\hline \multicolumn{5}{|l|}{ Cardiac and cerebral disorders ${ }^{\mathrm{b}}$} \\
\hline Lacunar infarction, \% & 29.1 & 37.2 & 25.2 & 0.0007 \\
\hline White matter hyperintensity, \% & 42.7 & 43.6 & 42.3 & 0.7 \\
\hline Left ventricular hypertrophy, \% & 14.7 & 17.3 & 13.5 & 0.2 \\
\hline Daytime systolic, mm Hg & $131.9 \pm 13.7$ & $133.5 \pm 13.1$ & $131.2 \pm 13.9$ & 0.03 \\
\hline Daytime diastolic, mm Hg & $77.5 \pm 8.1$ & $79.2 \pm 7.4$ & $76.7 \pm 8.3$ & $<0.0001$ \\
\hline Nighttime systolic, mm Hg & $114.5 \pm 14.0$ & $117.7 \pm 13.3$ & $113.0 \pm 14.1$ & $<0.0001$ \\
\hline Nighttime diastolic, $\mathrm{mm} \mathrm{Hg}$ & $65.0 \pm 7.6$ & $67.7 \pm 7.2$ & $63.8 \pm 7.5$ & $<0.0001$ \\
\hline \multicolumn{5}{|l|}{ Casual blood pressure } \\
\hline Systolic, mm Hg & $141.9 \pm 20.0$ & $142.6 \pm 19.2$ & $141.6 \pm 20.3$ & 0.5 \\
\hline Diastolic, mm Hg & $78.4 \pm 10.4$ & $79.5 \pm 10.9$ & $77.9 \pm 10.2$ & 0.06 \\
\hline Serum creatinine, $\mathrm{mg} \mathrm{dl}^{-1}$ & $0.82 \pm 0.18$ & $0.92 \pm 0.22$ & $0.78 \pm 0.13$ & $<0.0001$ \\
\hline Plasma renin activityc ${ }^{c} \mathrm{ng} \mathrm{ml}^{-1} \mathrm{~h}^{-1}$ & $1.0(0.5-1.7)$ & $1.3(0.7-2.4)$ & $0.9(0.5-1.5)$ & $<0.0001$ \\
\hline
\end{tabular}

aMen vs. women.

bNumber of cardiac and cerebral disorders: 738, lacunar infarction and white matter hyperintensity; 662 , left ventricular hypertrophy.

'Plasma renin activity levels are expressed as median (interquartile range), and transformed into natural logarithm before analysis.

Table 2 Genotype and allele frequencies of $-782 A>G$, IVS5+169C $>$ T and $+1513 A>G$

\begin{tabular}{|c|c|c|c|c|c|}
\hline \multirow[b]{2}{*}{$-782 A>G$} & \multicolumn{3}{|c|}{ Genotype frequencies } & \multicolumn{2}{|c|}{ Allele frequencies } \\
\hline & $\mathrm{AA}$ & $A G$ & GG & A & G \\
\hline Men $(n=250)$ & - & - & - & $215(86.0)$ & $35(14.0$ \\
\hline IVS5+169C > T & $\mathrm{CC}$ & CT & $\mathrm{TT}$ & C & $\mathrm{T}$ \\
\hline Men $(n=250)$ & - & - & - & $214(85.6)$ & $36(14.4$ \\
\hline Women $(n=529)$ & $411(77.7)$ & $108(20.4)$ & $10(1.9)$ & $930(87.9)$ & $128(12.1$ \\
\hline Women $(n=529)$ & $313(59.2)$ & $190(35.9)$ & $26(4.9)$ & $816(77.1)$ & $242(22.9$ \\
\hline
\end{tabular}

Data are expressed as number of persons (\%). As (pro)renin receptor gene is located on the $\mathrm{X}$ chromosome, genotype data were not available in men.

(Table 3). The prevalence of WMH tended to be higher in women with +1513 GG genotype $(61.5 \%)$ than in those with AA genotype (41.1\%) and AG genotype (37.6\%), but differences did not reach statistical significance $(P=0.07)$. In contrast, no statistically significant differences in prevalence of lacunar infarction, WMH and LVH were found for the two other SNPs examined $(-782 \mathrm{~A}>\mathrm{G}$ and IVS5+169C $>$ T).

Moreover, $+1513 \mathrm{~A}>\mathrm{G}$ was significantly associated with PRA levels in women. PRA levels in women with the GG genotype were significantly lower than in women with the other genotypes (AA, 0.9 (0.5-1.5); AG, 0.9 (0.5-1.5); and GG, $0.6(0.3-1.3) ; P=0.01)$. Other clinical characteristics, biochemical parameters and blood pressure were not significantly different among the three genotypes. In addition, we reconstructed haplotypes from the three SNPs $(-782 \mathrm{~A}>\mathrm{G}$, IVS5+169C $>\mathrm{T}$ and $+1513 \mathrm{~A}>\mathrm{G}$ ) to examine the association of haplotypes with lacunar infarction, WMH, LVH and PRA. No significant associations were observed in men or women.

The adjusted odds ratios and 95\% confidence intervals (95\% CIs) for lacunar infarction and $\mathrm{LVH}$ among the $+1513 \mathrm{~A}>\mathrm{G}$ genotype in women are shown in Figure 1. After adjusting for confounding factors, such as age, body mass index, 24-h ABP (systolic), smoking status (current or not), alcohol intake (current or not), prevalence of 
Table 3 Prevalence of lacunar infarction, white matter hyperintensity and left ventricular hypertrophy

\begin{tabular}{|c|c|c|c|c|c|c|c|}
\hline \multirow[b]{2}{*}{$-782 A>G$} & \multicolumn{3}{|c|}{ Men } & \multicolumn{4}{|c|}{ Women } \\
\hline & A & G & $P$-value & $\mathrm{AA}$ & $A G$ & GG & $P$-value \\
\hline Lacunar infarction & $65(32.8)$ & $16(47.1)$ & 0.1 & $95(24.4)$ & $24(23.1)$ & $4(30.8)$ & 0.8 \\
\hline Left ventricular hypertrophy & 35 (19.3) & $3(11.5)$ & 0.3 & 49 (14.0) & $16(17.0)$ & $1(9.1)$ & 0.7 \\
\hline IVS5+169C > T & C & $T$ & $P$-value & $\mathrm{CC}$ & CT & $\mathrm{TT}$ & $P$-value \\
\hline Lacunar infarction & $65(33.0)$ & $16(45.7)$ & 0.2 & $95(24.2)$ & $26(25.0)$ & $2(20.0)$ & 0.9 \\
\hline$+1513 A>G$ & A & G & $P$-value & AA & $A G$ & GG & $P$-value \\
\hline Lacunar infarction & $61(34.9)$ & $20(35.1)$ & 1 & $67(22.2)$ & $43(24.2)$ & $13(50.0)$ & 0.01 \\
\hline White matter hyperintensity & 75 (42.9) & $23(40.4)$ & 0.7 & $124(41.1)$ & $67(37.6)$ & $16(61.5)$ & 0.07 \\
\hline Left ventricular hypertrophy & $32(20.3)$ & $6(12.2)$ & 0.2 & $27(10.1)$ & $32(19.4)$ & 7 (31.8) & 0.003 \\
\hline
\end{tabular}

Data are expressed as number (\%). P-value calculated by $\chi^{2}$ test for prevalence of disorders among the (P)RR gene genotypes. $N$ of cardiac and cerebral disorders: 738 , lacunar infarction and white matter hyperintensity; 662, left ventricular hypertrophy.
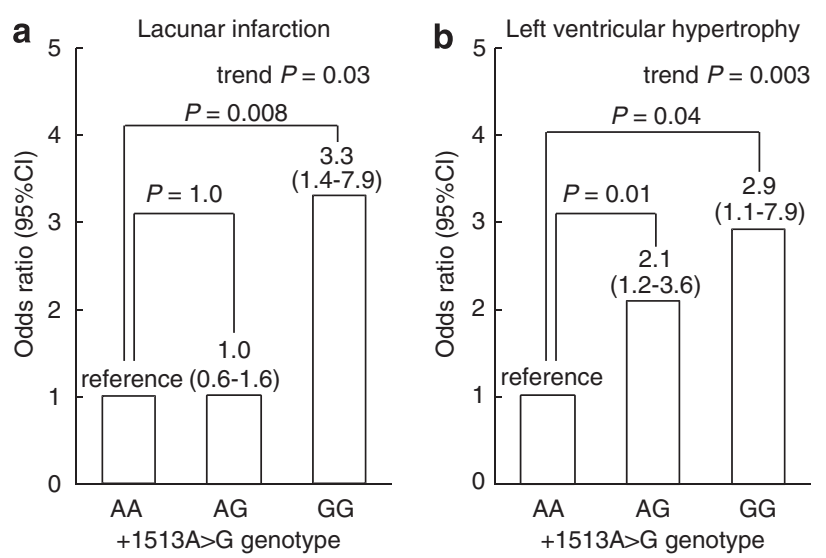

Figure 1 Adjusted odds ratios and 95\% confidence intervals for the risk of (a) lacunar infarction and (b) left ventricular hypertrophy among the $+1513 \mathrm{~A}>\mathrm{G}$ genotype in women. Findings were adjusted for cardiovascular risks, such as age, body mass index, 24-h ambulatory blood pressure (systolic), smoking status (current or not), alcohol intake (current or not), prevalence of diabetes mellitus, antihypertensive medication, prevalence of hypercholesterolemia, history of cardiovascular disease and plasma renin activity.

diabetes mellitus, antihypertensive medication, prevalence of hypercholesterolemia, history of cardiovascular disease and PRA, the $+1513 \mathrm{~A}>\mathrm{G}$ genotype was significantly and independently related to the risk for lacunar infarction (trend $P=0.03$, Figure 1a), and LVH (trend $P=0.003$, Figure $1 \mathrm{~b}$ ). The odds ratio for the risk of lacunar infarction with AG and GG genotype compared with AA genotype was 1.0 (95\% CI 0.6-1.6) and 3.3 (95\% CI 1.4-7.9), respectively. The odds ratio for the risk of $\mathrm{LVH}$ with $\mathrm{AG}$ and GG genotype compared with AA genotype was 2.1 (95\% CI 1.2-3.6) and 2.9 (95\% CI 1.1-7.9), respectively.

\section{DISCUSSION}

Four SNPs with amino-acid substitutions (F30L, P43A, P90A and A290P), which might be directly related to (P)RR protein structure and function, were registered in the SNP database of the National Center for Biotechnology Information. Ramser et al. ${ }^{16}$ reported that a mutation (c.321C > T, p.D107D) in human (P)RR gene resulted in $\mathrm{X}$-linked mental retardation and epilepsy. These mutations, however, were not found in our participants. ${ }^{17}$ Moreover, except for the blood pressure, ${ }^{17,18}$ there were no reports showing the association of $(\mathrm{P}) \mathrm{RR}$ polymorphism with clinical phenotype, such as diabetes mellitus, renal injury and organ damage. This study has found for the first time an association between (P)RR gene polymorphism, and cardiac and cerebral disorders.

In women with the $+1513 \mathrm{GG}$ genotype, the prevalence of lacunar infarction and LVH were significantly higher, and prevalence of WMH tended to be higher than those with the AA or AG genotypes. Moreover, the risks of lacunar infarction and LVH were significantly higher after adjusting for traditional cardiovascular risks including age, body mass index, blood pressure, diabetes mellitus and hypercholesterolemia. Our results suggest that the $(\mathrm{P}) \mathrm{RR}+1513 \mathrm{~A}>\mathrm{G}$ polymorphism may be an independent risk factor for cardiac and cerebral organ damage in women.

The $(\mathrm{P}) \mathrm{RR}$ has been reported to contribute to the development of cardiac and renal damage in several animal studies. ${ }^{5-12}$ In vitro studies using small interfering RNA have been demonstrated that knockdown of (P)RR suppressed fibrotic factor release in rat cultured vascular smooth muscle cells and mesangial cells. ${ }^{28,29}$ Moreover, the (P)RR has been reported to cause nonproteolytic activation of prorenin and directly activate intracellular signaling pathways independently of the RAS. ${ }^{1,30}$ Saris et al. ${ }^{31}$ reported that prorenin-induced intracellular signaling in cardiomyocytes independently of angiotensin II and suggested that prorenin directly affected cardiac growth and development via the (P)RR-mediated activation of ERK1/2. Alternatively, Véniant et al. ${ }^{32}$ observed progression of vascular damage without an increase in blood pressure in rats with overexpression of prorenin gene. Together with these results, our study supports that idea that (P)RR might promote the progression of cardiac and cerebral abnormalities without increasing blood pressure in humans.

In men, our previous study showed that the $(\mathrm{P}) \mathrm{RR}$ gene polymorphism, IVS5+169C $>\mathrm{T}$, was significantly associated with ABP in the same population. ${ }^{17}$ No significant association, however, was observed between (P)RR gene polymorphism and cardiac and cerebral disorders. It was reported that sex hormones, such as testosterone and estrogen affected the activity of the RAS, ${ }^{33}$ and that polymorphisms of RAS components had gender-specific associations. ${ }^{34-36}$ Therefore, the expression or role of the (P)RR in cardiac and cerebral tissues may be different between men and women, and (P)RR might have dual functions, that is, regulation of blood pressure and generation of tissue damage. We, however, could not deny the possibility that large 
differences in clinical characteristics between the men and women in this study may have affected the gender-specific association.

The biological mechanism working in the association of the $+1513 \mathrm{~A}>\mathrm{G}$ polymorphism with lacunar infarction and LVH is unclear. The $+1513 \mathrm{~A}>\mathrm{G}$ is located on the $3^{\prime}$-untranslated region in the $(\mathrm{P}) \mathrm{RR}$ gene and completely linked with one SNP in the exon8 and four SNPs in the $3^{\prime}$-untranslated region. ${ }^{17}$ These SNPs, however, are located on non-coding regions or result in no amino-acid substitution. ${ }^{17}$ It was reported that a silent mutation in exon4 of the human (P)RR gene (c321C > T, p.D107D) enhanced the expression of (P)RR that lacked exon4. ${ }^{16}$ This mutant receptor could bind to renin and increase renin catalytic activity, similarly to the wild-type receptor, but resulting in a modest and reproducible impairment of ERK1/2 activation. ${ }^{16}$ Therefore, these SNPs might result in abnormalities of the gene expression processes, such as transcription, splicing and posttranscriptional regulation. It was reported that the regulation sites for the $(\mathrm{P}) \mathrm{RR}$ expression were located in the untranslated region of the (P)RR gene, and several studies have shown that polymorphisms in the non-coding region result in abnormalities of gene expression. ${ }^{37}$ Consequently, the expression of the $(\mathrm{P}) \mathrm{RR}$ gene may increase in women with the $G$ allele carrier, and high expression of the $(P) R R$ gene may result in cardiac and cerebral damage such as lacunar infarction and LVH.

Low PRA levels were observed in women with the +1513GG genotype. It is unclear why $(\mathrm{P}) \mathrm{RR}$ polymorphism is associated with low PRA levels. The parallel increase in renin and (P)RR expression was observed in the clipped kidney of Goldblatt hypertensive rats, ${ }^{38}$ and some animal studies have reported that (P)RR expression was not associated with PRA levels. ${ }^{8,9}$ As other RAS parameters were not measured in this study, such as plasma prorenin, renin, angiotensin and aldosterone concentrations, further investigations are needed to determine the association of (P)RR with the activities of RAS components.

This study has some limitations. First, there are no functional studies to substantiate why (P)RR gene polymorphism induces organ damage, nor data to explain why the association is sex specific. Recently, Cousin et al. ${ }^{39}$ reported the soluble form of (P)RR in human plasma. The soluble form of (P)RR may explain the sexdifference association of $(\mathrm{P}) \mathrm{RR}$ and the relation to PRA, but there are no specific method to measure plasma soluble (P)RR. In addition, this study had limited statistical power because of its small sample size. This may be affect to the dominant and recessive association of the $+1513 \mathrm{~A}>\mathrm{G}$ polymorphism in lacunar infarction and LVH. Further investigations in other races or in longitudinal studies are required to clarify the association of the $(\mathrm{P}) \mathrm{RR}$ gene polymorphism with blood pressure regulation or organ damage.

In conclusion, our results show that $(\mathrm{P}) \mathrm{RR}$ gene polymorphisms are involved in the pathogenesis of cardiac and cerebral disorders independent of regulation of blood pressure in Japanese women. Given the present study's findings, $(\mathrm{P}) \mathrm{RR}$ has a potential role in cardio- and cerebrovascular diseases in humans.

\section{CONFLICT OF INTEREST}

The authors declare no conflict of interest.

\section{ACKNOWLEDGEMENTS}

We are grateful to the residents in Ohasama Town, all investigators and study staff, and staff members of the Hanamaki City Government, Ohasama Hospital and Iwate Prefectural Stroke Registry for their valuable support on this project. This study was performed in part using equipment in the Biomedical Research Core of Tohoku University Graduate School of Medicine. This study was supported in part by Grants for Scientific Research (18390192, 18590587, 19590929, 19790423, 20590629, 21300198, 21390201, 21591016, 22590767 and 22790556) from the Ministry of Education, Culture, Sports, Science and Technology, Japan; Grant-in-Aid (H18-Junkankitou(Seishuu)-Ippan-012, and H20-Junkankitou(Seishuu)-Ippan-009, 013) from the Ministry of Health, Labor and Welfare, Health and Labor Sciences Research Grants, Japan; Grantin-Aid for Japan Society for the Promotion of Science (JSPS) fellows (18.54042, 19.7152, 20.7198, 20.7477 and 20.54043); Health Science Research Grants and Medical Technology Evaluation Research Grants from the Ministry of Health, Labor and Welfare, Japan; Japan Atherosclerosis Prevention Fund; Uehara Memorial Foundation; Takeda Medical Research Foundation; National Cardiovascular Research Grants; and Biomedical Innovation Grants.

1 Nguyen G, Delarue F, Burckle C, Bouzhir L, Giller T, Sraer JD. Pivotal role of the renin/ prorenin receptor in angiotensin II production and cellular responses to renin. J Clin Invest 2002; 109: 1417-1427.

2 Takahashi K, Hiraishi K, Hirose T, Kato I, Yamamoto H, Shoji I, Shibasaki A, Kaneko K, Satoh F, Totsune K. Expression of (pro)renin receptor in the human brain and pituitary, and co-localisation with arginine vasopressin and oxytocin in the hypothalamus. J Neuroendocrinol 2010; 22: 453-459.

3 Takahashi K, Yamamoto H, Hirose T, Hiraishi K, Shoji I, Shibasaki A, Kato I, Kaneko K, Sasano H, Satoh F, Totsune K. Expression of (pro)renin receptor in human kidneys with end-stage kidney disease due to diabetic nephropathy. Peptides 2010; 31: $1405-1408$.

4 Huang Y, Wongamorntham S, Kasting J, McQuillan D, Owens RT, Yu L, Noble NA, Border W. Renin increases mesangial cell transforming growth factor-betal and matrix proteins through receptor-mediated, angiotensin II-independent mechanisms. Kidney Int 2006; 69: 105-113.

5 Burcklé CA, Jan Danser AH, Muller DN, Garrelds IM, Gasc JM, Popova E, Plehm R, Peters J, Bader M, Nguyen G. Elevated blood pressure and heart rate in human renin receptor transgenic rats. Hypertension 2006; 47: 552-556.

6 Ichihara A, Hayashi M, Kaneshiro Y, Suzuki F, Nakagawa T, Tada Y, Koura Y, Nishiyama A, Okada H, Uddin MN, Nabi AH, Ishida Y, Inagami T, Saruta T. Inhibition of diabetic nephropathy by a decoy peptide corresponding to the 'handle' region for nonproteolytic activation of prorenin. J Clin Invest 2004; 114: 1128-1135.

7 Ichihara A, Kaneshiro Y, Takemitsu T, Sakoda M, Nakagawa T, Nishiyama A, Kawachi H, Shimizu F, Inagami T. Contribution of nonproteolytically activated prorenin in glomeruli to hypertensive renal damage. J Am Soc Nephrol 2006; 17: 2495-2503.

8 Ichihara A, Kaneshiro Y, Takemitsu T, Sakoda M, Suzuki F, Nakagawa T, Nishiyama A, Inagami T, Hayashi M. Nonproteolytic activation of prorenin contributes to development of cardiac fibrosis in genetic hypertension. Hypertension 2006; 47: 894-900.

9 Ichihara A, Suzuki F, Nakagawa T, Kaneshiro Y, Takemitsu T, Sakoda M, Nabi AH, Nishiyama A, Sugaya T, Hayashi M, Inagami T. Prorenin receptor blockade inhibits development of glomerulosclerosis in diabetic angiotensin II type 1a receptor-deficient mice. J Am Soc Nephrol 2006; 17: 1950-1961.

10 Kaneshiro Y, Ichihara A, Sakoda M, Takemitsu T, Nabi AH, Uddin MN, Nakagawa T, Nishiyama A, Suzuki F, Inagami T, Itoh H. Slowly progressive, angiotensin II-independent glomerulosclerosis in human (pro)renin receptor-transgenic rats. J Am Soc Nephrol 2007; 18: 1789-1795

11 Kinouchi K, Ichihara A, Sano M, Sun-Wada GH, Wada Y, Kurauchi-Mito A, Bokuda K, Narita T, Oshima Y, Sakoda M, Tamai Y, Sato H, Fukuda K, Itoh H. The (pro)renin receptor/ATP6AP2 is essential for vacuolar H+-ATPase assembly in murine cardiomyocytes. Circ Res 2010; 107: 30-34.

12 Susic D, Zhou X, Frohlich ED, Lippton H, Knight M. Cardiovascular effects of prorenin blockade in genetically spontaneously hypertensive rats on normal and high-salt diet. Am J Physiol Heart Circ Physiol 2008; 295: H1117-H1121.

13 Hirose T, Mori N, Totsune K, Morimoto R, Maejima T, Kawamura T, Metoki H, Asayama K, Kikuya M, Ohkubo T, Kohzuki M, Takahashi K, Imai Y. Gene expression of (pro)renin receptor is upregulated in hearts and kidneys of rats with congestive heart failure. Peptides 2009; 30: 2316-2322.

14 Hirose T, Mori N, Totsune K, Morimoto R, Maejima T, Kawamura T, Metoki H, Asayama K, Kikuya M, Ohkubo T, Kohzuki M, Takahashi K, Imai Y. Increased expression of (pro)renin receptor in the remnant kidneys of $5 / 6$ nephrectomized rats. Regul Pept 2010; 159: 93-99.

15 Perola M, Kainulainen K, Pajukanta P, Terwilliger JD, Hiekkalinna T, Ellonen P, Kaprio J, Koskenvuo M, Kontula K, Peltonen L. Genome-wide scan of predisposing loci for increased diastolic blood pressure in Finnish siblings. J Hypertens 2000; 18: 1579-1585.

16 Ramser J, Abidi FE, Burckle CA, Lenski C, Toriello H, Wen G, Lubs HA, Engert S, Stevenson RE, Meindl A, Schwartz CE, Nguyen G. A unique exonic splice enhancer mutation in a family with $\mathrm{X}$-linked mental retardation and epilepsy points to a novel role of the renin receptor. Hum Mol Genet 2005; 14: 1019-1027.

17 Hirose T, Hashimoto M, Totsune K, Metoki H, Asayama K, Kikuya M, Sugimoto K, Katsuya T, Ohkubo T, Hashimoto J, Rakugi H, Takahashi K, Imai Y. Association of (pro)renin receptor gene polymorphism with blood pressure in Japanese men: the Ohasama study. Am J Hypertens 2009; 22: 294-299. 
18 Ott C, Schneider M, Hilgers K, Schmieder R. Association of (pro)renin receptor gene polymorphism with blood pressure in men. J Hypertens 2010; 28: e346. Abstract.

19 Imai Y, Nagai K, Sakuma M, Sakuma H, Nakatsuka H, Satoh H, Minami N, Munakata M, Hashimoto J, Yamagishi T, Yabe T, Nishiyama A, Abe K. Ambulatory blood pressure of adults in Ohasama, Japan. Hypertension 1993; 22: 900-912.

20 Imai Y, Satoh H, Nagai K, Sakuma M, Sakuma H, Minami N, Munakata M, Hashimoto J, Yamagishi T, Watanabe N, Yabe T, Nishiyama A, Nakatsuka H, Koyama H, Abe K. Characteristics of a community-based distribution of home blood pressure in Ohasama in northern Japan. J Hypertens 1993; 11: 1441-1449.

21 Expert Committee on the Diagnosis and Classification of Diabetes Mellitus. Report of the expert committee on the diagnosis and classification of diabetes mellitus. Diabetes Care 2003; 26: S5-S20.

22 Imai Y, Abe K, Sasaki S, Minami N, Munakata M, Sekino H, Nihei M, Yoshinaga K. Determination of clinical accuracy and nocturnal blood pressure pattern by new portable device for monitoring indirect ambulatory blood pressure. Am J Hypertens 1990; 3: 293-301.

23 Association for the Advancement of Medical Instrumentation. American National Standards for Electronic or Automated Sphygmomanometers. AAMI Analysis and Review: Washington, DC, 1987.

24 Ogihara T, Kikuchi K, Matsuoka H, Fujita T, Higaki J, Horiuchi M, Imai Y, Imaizumi T, Ito S, Iwao H, Kario K, Kawano Y, Kim-Mitsuyama S, Kimura G, Matsubara H, Matsuura H, Naruse M, Saito I, Shimada K, Shimamoto K, Suzuki H, Takishita S, Tanahashi N, Tsuchihashi T, Uchiyama M, Ueda S, Ueshima H, Umemura S, Ishimitsu T, Rakugi H. The Japanese Society of Hypertension Guidelines for the Management of Hypertension (JSH 2009). Hypertens Res 2009; 32: 3-107.

25 Aono Y, Ohkubo T, Kikuya M, Hara A, Kondo T, Obara T, Metoki H, Inoue R, Asayama K, Shintani Y, Hashimoto J, Totsune K, Hoshi H, Satoh H, Izumi S, Imai Y. Plasma fibrinogen, ambulatory blood pressure, and silent cerebrovascular lesions: the Ohasama study. Arterioscler Thromb Vasc Biol 2007; 27: 963-968.

26 Watabe D, Hashimoto J, Hatanaka R, Hanazawa T, Ohba H, Ohkubo T, Kikuya M, Totsune K, Imai Y. Electrocardiographic left ventricular hypertrophy and arterial stiffness: the Ohasama study. Am J Hypertens 2006; 19: 1199-1205.

27 Dahlof B, Devereux R, de Faire U, Fyhrquist F, Hedner T, Ibsen H, Julius S, Kjeldsen S, Kristianson K, Lederballe-Pedersen O, Lindholm LH, Nieminen MS, Omvik P, Oparil S, Wedel $\mathrm{H}$. The Losartan intervention for endpoint reduction (LIFE) in hypertension study: rationale, design, and methods. The LIFE Study Group. Am J Hypertens 1997; 10: 705-713.
28 He M, Zhang L, Shao Y, Wang X, Huang Y, Yao T, Lu L. Inhibition of renin/prorenin receptor attenuated mesangial cell proliferation and reduced associated fibrotic factor release. Eur J Pharmacol 2009; 606: 155-161.

29 Zhang J, Noble NA, Border WA, Owens RT, Huang Y. Receptor-dependent prorenin activation and induction of PAI-1 expression in vascular smooth muscle cells. Am J Physiol Endocrinol Metab 2008; 295: E810-E819.

30 Huang Y, Noble NA, Zhang J, Xu C, Border WA. Renin-stimulated TGF-beta1 expression is regulated by a mitogen-activated protein kinase in mesangial cells. Kidney Int 2007; 72: 45-52.

31 Saris JJ, t Hoen PA, Garrelds IM, Dekkers DH, den Dunnen JT, Lamers JM, Jan Danser $\mathrm{AH}$. Prorenin induces intracellular signaling in cardiomyocytes independently of angiotensin II. Hypertension 2006; 48: 564-571.

32 Veniant M, Menard J, Bruneval P, Morley S, Gonzales MF, Mullins J. Vascular damage without hypertension in transgenic rats expressing prorenin exclusively in the liver. J Clin Invest 1996; 98: 1966-1970.

33 Fischer M, Baessler A, Schunkert $H$. Renin angiotensin system and gender differences in the cardiovascular system. Cardiovasc Res 2002; 53: 672-677.

34 Lynch AI, Arnett DK, Pankow JS, Miller MB, North KE, Eckfeldt JH, Hunt SC, Rao DC, Djousse L. Sex-specific effects of ACE I/D and AGT-M235T on pulse pressure: the HyperGEN Study. Hum Genet 2007; 122: 33-40.

35 Mansego ML, Redon J, Marin R, Gonzalez-Albert V, Martin-Escudero JC, Fabia MJ, Martinez F, Chaves FJ. Renin polymorphisms and haplotypes are associated with blood pressure levels and hypertension risk in postmenopausal women. J Hypertens 2008; 26: 230-237.

36 Higaki J, Baba S, Katsuya T, Sato N, Ishikawa K, Mannami T, Ogata J, Ogihara T. Deletion allele of angiotensin-converting enzyme gene increases risk of essential hypertension in Japanese men: the Suita Study. Circulation 2000; 101: 2060-2065.

37 Sethupathy P, Borel C, Gagnebin M, Grant GR, Deutsch S, Elton TS, Hatzigeorgiou AG, Antonarakis SE. Human microRNA-155 on chromosome 21 differentially interacts with its polymorphic target in the AGTR1 $3^{\prime}$ untranslated region: a mechanism for functional single-nucleotide polymorphisms related to phenotypes. Am J Hum Genet 2007; 81: 405-413.

38 Krebs C, Hamming I, Sadaghiani S, Steinmetz OM, Meyer-Schwesinger C, Fehr S, Stahl RA, Garrelds IM, Danser AH, van Goor H, Contrepas A, Nguyen G, Wenzel U. Antihypertensive therapy upregulates renin and (pro)renin receptor in the clipped kidney of Goldblatt hypertensive rats. Kidney Int 2007; 72: 725-730.

39 Cousin C, Bracquart D, Contrepas A, Corvol P, Muller L, Nguyen G. Soluble form of the (pro)renin receptor generated by intracellular cleavage by furin is secreted in plasma. Hypertension 2009; 53: 1077-1082. 